\title{
Facile Synthesis of PdCuRu Porous Nanoplates as Highly Efficient Electrocatalysts for Hydrogen Evolution Reaction in Alkaline Medium
}

\author{
Changhong Chen ${ }^{1}$, Ningkang Qian ${ }^{1}$, Junjie Li ${ }^{1}$, Xiao Li ${ }^{1}$, Deren Yang ${ }^{1}$ and Hui Zhang ${ }^{1,2, *}$ \\ 1 State Key Laboratory of Silicon Materials and School of Materials Science \& Engineering, Zhejiang University, \\ Hangzhou 310027, China; 21826054@zju.edu.cn (C.C.); 3140102831@zju.edu.cn (N.Q.); \\ 3140104160@zju.edu.cn (J.L.); 11726026@zju.edu.cn (X.L.); mseyang@zju.edu.cn (D.Y.) \\ 2 Institute of Advanced Semiconductors, Hangzhou Innovation Center, Zhejiang University, \\ Hangzhou 310027, China \\ * Correspondence: msezhanghui@zju.edu.cn; Tel.: +86-571-8795-1667
}

Citation: Chen, C.; Qian, N.; Li, J.; Li,

X.; Yang, D.; Zhang, H. Facile

Synthesis of PdCuRu Porous

Nanoplates as Highly Efficient

Electrocatalysts for Hydrogen

Evolution Reaction in Alkaline

Medium. Metals 2021, 11, 1451.

https://doi.org/10.3390/met11091451

Academic Editor: Imre Bakonyi

Received: 2 August 2021

Accepted: 6 September 2021

Published: 13 September 2021

Publisher's Note: MDPI stays neutral with regard to jurisdictional claims in published maps and institutional affiliations.

Copyright: (c) 2021 by the authors. Licensee MDPI, Basel, Switzerland. This article is an open access article distributed under the terms and conditions of the Creative Commons Attribution (CC BY) license (https:// creativecommons.org/licenses/by/ $4.0 /)$.

\begin{abstract}
Ru is a key component of electrocatalysts for hydrogen evolution reaction (HER), especially in alkaline media. However, the catalytic activity and durability of Ru-based HER electrocatalysts are still far from satisfactory. Here we report a solvothermal approach for the synthesis of PdCuRu porous nanoplates with different Ru compositions by using Pd nanoplates as the seeds. The PdCuRu porous nanoplates were formed through underpotential deposition (UPD) of $\mathrm{Cu}$ on Pd, followed by alloying $\mathrm{Cu}$ with $\mathrm{Pd}$ through interdiffusion and galvanic replacement between $\mathrm{Cu}$ atoms and $\mathrm{Ru}$ precursor simultaneously. When evaluated as HER electrocatalysts, the PdCuRu porous nanoplates exhibited excellent catalytic activity and durability. Of them, the $\mathrm{Pd}_{24} \mathrm{Cu}_{29} \mathrm{Ru}_{47} / \mathrm{C}$ achieved the lowest overpotential $(40.7 \mathrm{mV})$ and smallest Tafel slope $\left(37.5 \mathrm{mV} \mathrm{dec}^{-1}\right)$ in an alkaline solution (much better than commercial $\mathrm{Pt} / \mathrm{C}$ ). In addition, the $\mathrm{Pd}_{24} \mathrm{Cu}_{29} \mathrm{Ru}_{47} / \mathrm{C}$ only lost $17 \%$ of its current density during a stability test for $10 \mathrm{~h}$, while commercial $\mathrm{Pt} / \mathrm{C}$ had a 59.5\% drop under the same conditions. We believe that the electron coupling between three metals, unique porous structure, and strong capability of $\mathrm{Ru}$ for water dissociation are responsible for such an enhancement in HER performance.
\end{abstract}

Keywords: Ru-based catalysts; hydrogen evolution reaction; porous structures; nanoplates; multimetallic alloys

\section{Introduction}

Ongoing global warming and energy crisis issues arising from the overuse of fossil fuels have prompted scientists to urgently search for clean and sustainable alternative energy sources [1-3]. In this regard, molecular hydrogen $\left(\mathrm{H}_{2}\right)$ is considered to be the most promising candidate due to its high-energy density without pollutant emission [4,5]. However, the production of $\mathrm{H}_{2}$ in the industry today still comes from the steam methane reforming process and requires high-energy input and a large amount of $\mathrm{CO}_{2}$ emission [6,7]. On the contrary, hydrogen evolution reaction (HER) is a half-cell reaction of electrochemical water splitting, which offers a green and sustainable approach for large-scale production of hydrogen with high-purity [8]. Until now, platinum (Pt) is still the critical component of electrocatalysts for HER, especially in acid media. However, the exorbitant cost and insufficient stockpile severely limit the widespread application of Pt-based electrocatalysts in HER [9]. Therefore, it is highly desirable to exploit new Pt-free electrocatalysts with remarkable HER performance, especially in alkaline solution, since Pt exhibits about two or three orders of magnitude lower activity in alkaline environments than acidic media [10].

Recently, ruthenium $(\mathrm{Ru})$ has received great attention as the key component of HER electrocatalysts, especially in alkaline media, due to its similar bond strength with hydrogen and relatively lower cost compared to $\mathrm{Pt}[11,12]$. For instance, Liu and co-workers reported the synthesis of Ru nanoparticles@C quantum dots (Ru@CQDs) hybrid materials, showing 
excellent catalytic properties for HER under alkaline condition [13]. In addition, much attention have been paid to Ru-based binary alloys since the introduction of second metal can improve the HER properties by electron coupling between two metals and bifunctional mechanisms [14-17]. Certainly, the cost of electrocatalysts can be reduce to one tenth by diluting noble metals with non-precious metals $[18,19]$. Despite the huge success in Ru-based nanocrystals, the exploration for Ru-based nanocrystals with unique structure and fantastic properties still continues, in particular for multimetallic alloys.

Over the last decade, two-dimensional (2D) nanomaterials with large lateral sizes and ultrathin thicknesses have attracted extensive attention owing to their rich variety of unconventional properties and widespread potential applications. These special geometry features associated with ultrathin 2D nanomaterials endow them with ultrahigh specific surface area, thereby making them promising candidates as advanced catalysts with excellent properties [20-25]. Unlike the intrinsically layered materials, most metals have a highly symmetric crystal lattice, leading to difficulty in the formation of 2D nanostructures thermodynamically [26,27]. Fortunately, many synthetic methods such as the addition of a capping agent or template with 2D structure have been developed to generate $2 \mathrm{D}$ metal nanostructures with well-controlled sizes, shapes, and compositions [28-34]. For example, Huang and co-workers reported the synthesis of unique sandwich-like Ru-Ni heterostructures with two hexagonal Ru rings caped on the two ends of a Ni pillar in the presence of polyvinyl pyrrolidone (PVP) serving as a capping agent [29]. In another study, we have developed a general and effective approach for the synthesis of Pt-based multimetallic ultrathin nanoplates with tunable thickness through epitaxial growth by using Pd nanoplates as the seeds [31]. In order to further increase the active sites of the nanoplates, the synthesis of porous 2D nanostructures is highly desirable.

Here, we report one-pot approach for synthesizing PdCuRu porous nanoplates by deposition of $\mathrm{CuRu}$ on Pd seeds. Such PdCuRu porous nanoplates with different compositions showed the excellent catalytic properties for HER. Of them, the $\mathrm{Pd}_{24} \mathrm{Cu}_{29} \mathrm{Ru}_{47}$ nanoplates achieved the highest activity and stability toward HER in an alkaline solution.

\section{Materials and Methods}

\subsection{Chemicals and Materials}

Palladium(II) acetylacetonate $\left(\mathrm{Pd}(\mathrm{acac})_{2}, 99 \%\right)$, ruthenium(III) acetylacetonate $\left(\mathrm{Ru}(\mathrm{acac})_{3}\right.$, 99\%), copper(II)acetylacetonate $\left(\mathrm{Cu}(\mathrm{acac})_{2}, 99 \%\right)$, polyvinylpyrrolidone (PVP, $\left.\mathrm{MW}=29000\right)$, oleylamine (OAm, 70\%), n-butylamine (98\%) and tungsten hexacarbonyl (W(CO) 6 , 97\%) were purchased from Sigma-Aldrich (Saint Louis, MO, USA). Oxalic acid (OA), cetyltrimethylammonium bromide (CTAB), N,N-dimethylformamide (DMF, AR), benzyl alcohol (BA, $\mathrm{AR})$, ethanol (AR), chloroform (AR), toluene (AR), cyclohexane (AR) and acetone (AR) were purchased from Sinopharm Chemical Reagent Co., Ltd. (Shanghai, China). All the chemicals were used as received without purification.

\subsection{Synthesis of Pd Nanoplates}

The Pd nanoplates with an average edge length of $19.8 \mathrm{~nm}$ and a thickness of $1.1 \mathrm{~nm}$ was synthesized through our previously reported method with slight modification $[35,36]$. Firstly, $16 \mathrm{mg}$ of $\mathrm{Pd}(\mathrm{acac})_{2}, 30 \mathrm{mg}$ of PVP, $60 \mathrm{mg}$ of CTAB and $30 \mathrm{mg}$ of OA were dissolved in $10 \mathrm{~mL}$ of DMF and stirred for $1 \mathrm{~h}$ at room temperature. Subsequently, the obtained homogeneous solution was transferred into a $25 \mathrm{~mL}$ glass flask and $100 \mathrm{mg}$ of $\mathrm{W}(\mathrm{CO})_{6}$ was then added in an Ar atmosphere. After that, the sealed flask was heated at $70{ }^{\circ} \mathrm{C}$ under magnetic stirring for $2 \mathrm{~h}$. Finally, the Pd nanoplates were collected by centrifugation, washed with ethanol for three times and re-dispersed in ethanol for further use. The formation mechanism (e.g., the role of each reactant) of the Pd nanoplates has been already discussed in our previous report [35]. 


\subsection{Synthesis of $P d C u R u$ Nanoplates with Different Compositions}

In a standard procedure for the synthesis of the $\mathrm{Pd}_{24} \mathrm{Cu}_{29} \mathrm{Ru}_{47}$ nanoplates, $120 \mathrm{mg}$ of PVP, $0.015 \mathrm{mmol}$ of $\mathrm{Cu}(\mathrm{acac})_{2}$, and $0.020 \mathrm{mmol}$ of $\mathrm{Ru}(\mathrm{acac})_{3}$ were dissolved in $10 \mathrm{~mL}$ of $\mathrm{BA}$ and stirred for $8 \mathrm{~h}$ at room temperature. $2 \mathrm{~mL}$ of as-synthesized Pd nanoplates was then added into the above-mentioned reaction solution. After stirring for $1 \mathrm{~h}$, the mixed homogeneous solution was transferred into a $15 \mathrm{~mL}$ Teflon-lined stainless-steel autoclave in an Ar atmosphere. Next, the sealed autoclave was heated at $200{ }^{\circ} \mathrm{C}$ for $12 \mathrm{~h}$. Finally, the product was collected by centrifugation using acetone and ethanol. This process was repeated three times. To obtain the $\mathrm{Pd}_{32} \mathrm{Cu}_{33} \mathrm{Ru}_{35}$ and $\mathrm{Pd}_{19} \mathrm{Cu}_{25} \mathrm{Ru}_{56}$ nanoplates, the amount of $\mathrm{Ru}(\mathrm{acac})_{3}$ fed in the synthesis was varied from 4 to $12 \mathrm{mg}$, respectively, with all other conditions being the same as the standard procedure.

\subsection{Phase-Transfer of PdCuRu Nanoplates into Hydrophobic Solvent}

For a clearer observation, the above-mentioned sample was re-dispersed in a mixture of ethanol, toluene and OAm with a volume ratio of 5:1:5. After stirring for $15 \mathrm{~min}$, the uniformly mixed solution was heated at $80^{\circ} \mathrm{C}$ for $12 \mathrm{~h}$. The final product was collected by centrifugation with ethanol and dispersed in cyclohexane.

\subsection{Morphological, Structural, and Compositional Characterizations}

The morphology of the sample was observed through transmission electron microscopy (TEM) with a Hitachi HT-7700 microscope operated at $100 \mathrm{kV}$ (Hitachi, Tokyo, Japan). High-resolution TEM (HRTEM) was performed using a FEI Tecnai F20 G2 microscope operated at $300 \mathrm{kV}$ (FEI, Hillsboro, OR, USA). Energy dispersive X-ray spectroscopy (EDX) mapping analyses were achieved on a FEI Titan ChemiSTEM equipped with a probe-corrector and a Super-X EDX detector system operated at $200 \mathrm{kV}$. The X-ray powder diffraction (XRD) patterns were recorded on a Bruker D8 focus diffractometer in a scan range of $5^{\circ}-80^{\circ}$ at a scan rate of $1.0^{\circ} \mathrm{min}^{-1}$. X-ray photoelectron spectrometry (XPS) was performed on a scanning X-ray microprobe (Axis Supra, Kratos Inc., Manchester, UK) with $\mathrm{Al} \mathrm{Ka}$ radiation. The percentages of the elements in the samples were detected using inductively coupled plasma atomic emission spectrometry (ICP-AES, IRIS Intrepid II XSP, TJA Co, Waltham, MA, USA).

\subsection{Electrochemical Measurements}

The electrochemical measurements were carried out at a CHI760E electrochemical analyzer (CHInstrument, Shanghai, China) based on a three-electrode cell. The working electrode was a glassy-carbon rotating disk electrode (RDE) (diameter: $5 \mathrm{~mm}$ and area: $0.196 \mathrm{~cm}^{2}$ ) from Pine Instruments. $\mathrm{An} \mathrm{Ag} / \mathrm{AgCl}$ electrode and a graphite rod were used as the reference electrode and the counter electrode, respectively. To prepare the working electrode, $5 \mathrm{mg}$ of catalyst and $25 \mu \mathrm{L}$ of Nafion 117 (Aldrich) was dispersed into $5 \mathrm{~mL}$ mixed solution containing DI water (Millipore, $18.2 \mathrm{M} \Omega$ ) and isopropanol with a volume ratio of 4:1. Then the mixture was sonicated for $30 \mathrm{~min}$ to form a homogeneous ink. After that, dozens of microliters of the ink were dropped onto the surface of RDE and dried at room temperature. Before electrochemical measurement, the working electrode was cleaned in the Ar-saturated $0.1 \mathrm{M} \mathrm{KOH}$ solution with a steady-state cyclic voltammetry (CV) scan for 20 cycles in the range of $0-1 \mathrm{~V}$ (vs. RHE) at a rate of $50 \mathrm{mV} \mathrm{s}^{-1}$. Linear sweep voltammetry (LSV) was performed at a scan rate of $2 \mathrm{mV} \mathrm{s}^{-1}$ in the range of $0-1 \mathrm{~V}$ (vs. RHE) with i-R compensation and a rotation speed of $1600 \mathrm{rpm}$ was used to remove hydrogen gas bubbles formed on the catalyst surface. The chronoamperometry (I-t) curves were measured at the overpotential when the current density reached $10 \mathrm{~mA} / \mathrm{cm}^{2}$.

\subsection{Measurements of Electrochemical Active Surface Area (ECSA)}

The ECSA of the samples was calculated through dividing the double layer capacitance $\left(\mathrm{Cd}_{1}\right)$ by the specific capacitance $\left(\mathrm{C}_{\mathrm{s}}\right)$ of the catalyst surface according to the equation: ECSA $=\mathrm{Cd}_{1} / \mathrm{C}_{\mathrm{s}}$. The $\mathrm{Cd}_{1}$ was determined by measuring $\mathrm{CVs}$ over a potential range of 
open-circuit potential (OCP) $\pm 0.1 \mathrm{~V}$, at multiple scan rates of $20,40,60,80,100,120,140$, 160,180 , and $200 \mathrm{mV} \mathrm{s}^{-1}$ in the non-Faradaic potential region. Then the slope derived from a plot of the measured charging current $\left(\mathrm{i}_{\mathrm{C}}\right)$ as a function of the scan rate $(\mathrm{v})$ is equal to $\mathrm{Cd}_{1}$. In this work, $\mathrm{C}_{\mathrm{s}}$ is taken $0.040 \mathrm{mF} \mathrm{cm}^{-2}$ for ECSA calculations.

\section{Results and Discussion}

The $\mathrm{Pd}_{24} \mathrm{Cu}_{29} \mathrm{Ru}_{47}$ multimetallic nanoplates were synthesized by a simple solvothermal method in benzyl alcohol (BA) using $\mathrm{Ru}(\mathrm{acac})_{3}$ and $\mathrm{Cu}(\mathrm{acac})_{2}$ as metal precursors under an inert atmosphere with Pd nanoplates as the seeds. From Figure S1, the hexagonal Pd nanoplates have an average edge length of ca. $19.28 \mathrm{~nm}$ and thickness of ca. $1.1 \mathrm{~nm}$. Figure 1 shows the morphological, structural, and compositional characterizations of the $\mathrm{Pd}_{24} \mathrm{Cu}_{29} \mathrm{Ru}_{47}$ nanoplates prepared using the standard procedure. From the TEM image in Figure 1a, the products retain the plate-like shape, whereas some porous structures with different sizes appear on the nanoplates. Such porous structures were confirmed by the HAADF-STEM image (Figure $1 b$ ). The thickness of the $\mathrm{Pd}_{24} \mathrm{Cu}_{29} \mathrm{Ru}_{47}$ nanoplates was measured to be ca. $5.5 \mathrm{~nm}$ with 25 atomic layers (Figure 1e and Figure S2). The thickness of the nanoplates were measured by mixing them with carbon nanotubes. The width of the projection for the vertically upstanding nanoplates is the corresponding thickness. As can be seen from the HRTEM image in Figure 1c, the distance of the lattice fringe in the interior of a nanoplates was measured to be $2.150 \AA$, which is located between $\operatorname{Pd}(111)$ with a lattice space of $2.246 \AA$ and $\mathrm{Cu}(111)$ with a lattice space of $2.088 \AA$, confirming the formation of the $\mathrm{PdCu}$ alloy. The elemental distribution of $\mathrm{Pd}, \mathrm{Ru}$, and $\mathrm{Cu}$ in the flat and vertically upstanding $\mathrm{Pd}_{24} \mathrm{Cu}_{29} \mathrm{Ru}_{47}$ nanoplates was determined by HAADF-STEM-EDX (FEI, Hillsboro, OR, USA) mapping and line-scan profile analyses, as shown in Figure 1d,e. As observed from Figure $1 \mathrm{~d}, \mathrm{Pd}$ and $\mathrm{Cu}$ are concentrated in the interior of the nanoplates, while Ru mainly exists on the surface of the nanoplates and only small amount of Ru scatters throughout the nanoplates. This demonstration was supported by the HAADF-STEM image of a vertically upstanding nanoplate (Figure 1e) and corresponding EDX line-scan analysis (FEI, Hillsboro, OR, USA) (Figure 1f). The formation of this structure was also consistent with the analysis for the formation process of the nanoplates (see next part). The atomic ratio of $\mathrm{Pd}, \mathrm{Cu}$, and $\mathrm{Ru}$ in the nanoplates was determined to be 24: 29: 47 through ICP-AES (Table S1), which is close to the feeding ratio of the metal precursors.
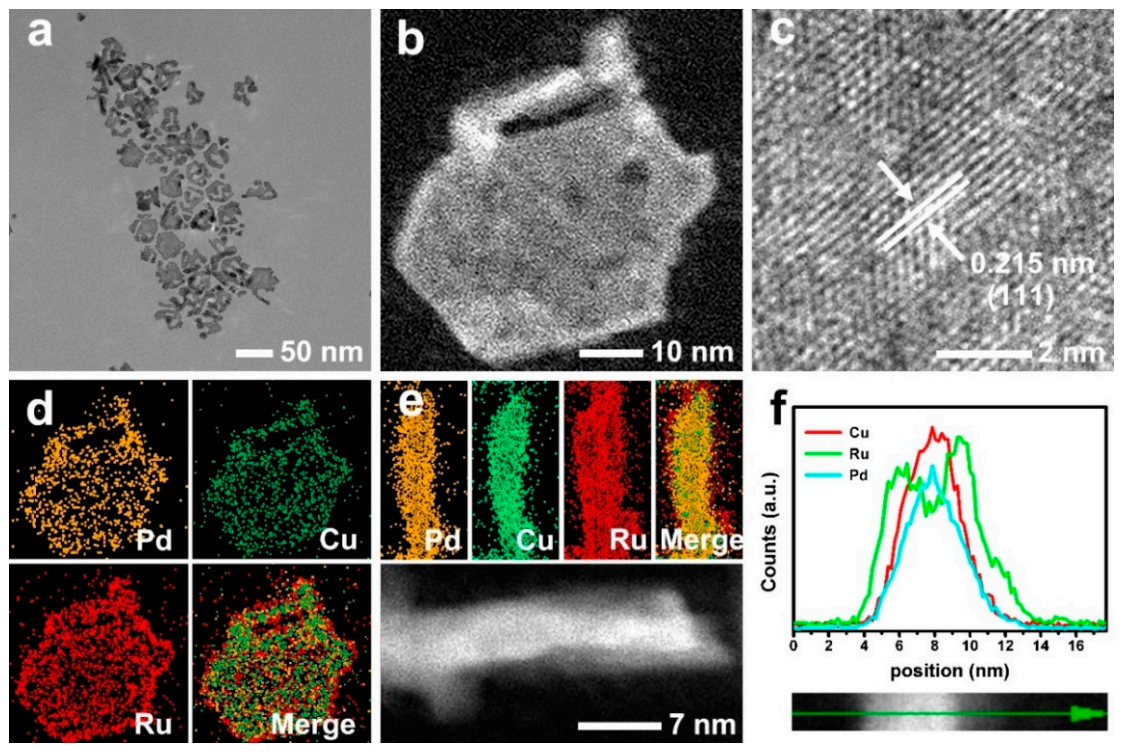

Figure 1. (a) TEM, (b) HAADF-STEM (c) HRTEM and (d) HAADF-STEM-EDX mapping images of a planar $\mathrm{Pd}_{24} \mathrm{Cu}_{29} \mathrm{Ru}_{47}$ nanoplate. (e) HAADF-STEM-EDX images of a vertically upstanding $\mathrm{Pd}_{24} \mathrm{Cu}_{29} \mathrm{Ru}_{47}$ nanoplate. $\mathrm{Pd}$ (orange), $\mathrm{Ru}(\mathrm{red})$, and $\mathrm{Cu}$ (green). (f) Line-scan profiles along the side of a $\mathrm{Pd}_{24} \mathrm{Cu}_{29} \mathrm{Ru}_{47}$ nanoplate. 
When the amount of the $\mathrm{Ru}$ precursor is varied from 4 to $12 \mathrm{mg}$, the porous nanoplates with similar shape and element distribution are also generated (Figures 2-4). The atomic ratio of $\mathrm{Pd}, \mathrm{Cu}$, and $\mathrm{Ru}$ in the nanoplates is varied to 32: 33: 35 and 19: 25: 56 (Table S1). We compared the size of the pores and their area percentage for above-mentioned three kinds of the nanoplates with different amounts of Ru (Figure S3). Due to the irregular shape of the pores, the data may not exactly accurate, but the trend is believable. With increasing amount of $\mathrm{Ru}$, the size and area percentage of the pores both decreased due to the deposition of Ru on the surface. This result is also consistent with the EDX mapping data that $\mathrm{Ru}$ is rich on the surface of the nanoplates (Figure 1e).

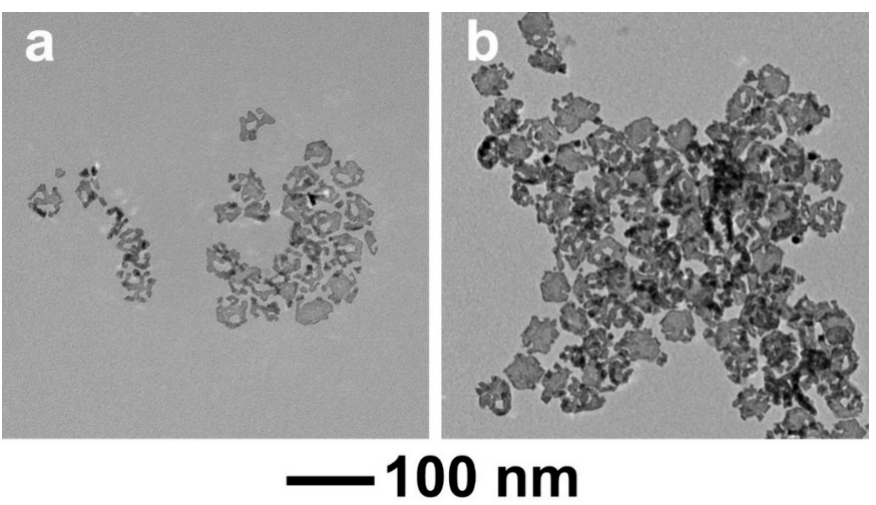

Figure 2. TEM images of the (a) $\mathrm{Pd}_{32} \mathrm{Cu}_{33} \mathrm{Ru}_{35}$ and (b) $\mathrm{Pd}_{19} \mathrm{Cu}_{25} \mathrm{Ru}_{56}$ nanoplates.
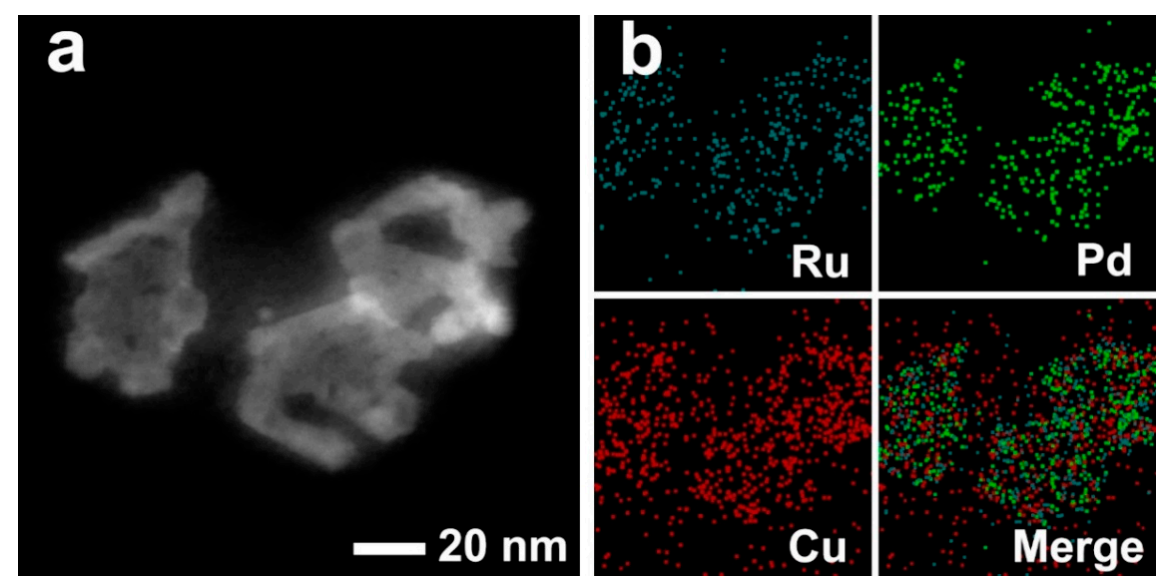

Figure 3. (a) HAADF-STEM and (b) EDX mapping images of the $\mathrm{Pd}_{32} \mathrm{Cu}_{33} \mathrm{Ru}_{35}$ nanoplates.
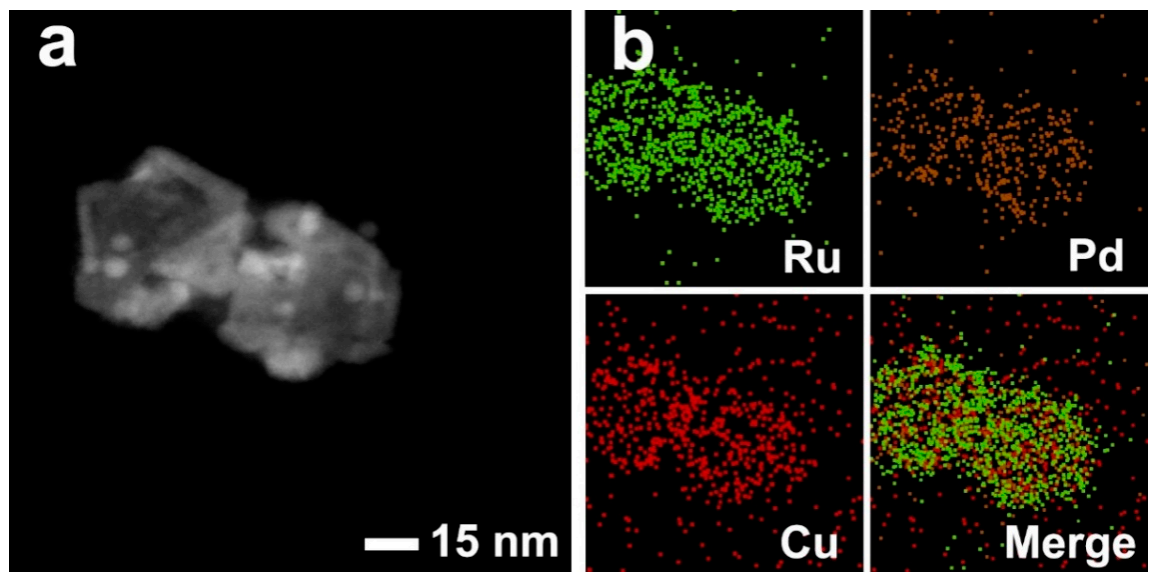

Figure 4. (a) HAADF-STEM and (b) EDX mapping images of the $\mathrm{Pd}_{19} \mathrm{Cu}_{25} \mathrm{Ru}_{56}$ nanoplates. 
The crystal structure of the nanoplates is further characterized by XRD analysis. As observed from the XRD patterns of the $\mathrm{Pd}_{24} \mathrm{Cu}_{29} \mathrm{Ru}_{47}$ nanoplates (Figure 5a), there are three typical diffraction peaks located at $41.56^{\circ}, 47.62^{\circ}$, and $70.35^{\circ}$, which can be assigned to (111), (200), and (220) planes of face-centered cubic ( $f c c)$ phases. The diffraction peaks are broadened a little due to the small and thin scale of the nanoplates. No diffraction peak associated with pure Pd, Cu or hexagonal close-packed $(h c p)$ Ru was detected. According to our previous report, the formation of the $f c c$-structured $\mathrm{Ru}$ is attributed to the induction of the Pd fcc lattice during the deposition of $\mathrm{Ru}$ atoms on Pd nanoplates [37]. With the increasing amount of $\mathrm{Ru}$, the diffraction peaks of the nanoplates are almost located at the same position due to the similar atomic size of Ru with other two atoms (Figure S4). Combined with the EDX data (Figure 1d,e), the nanoplates with an interior of PdCu alloys and a $\mathrm{Ru}$ richened surface were generated.
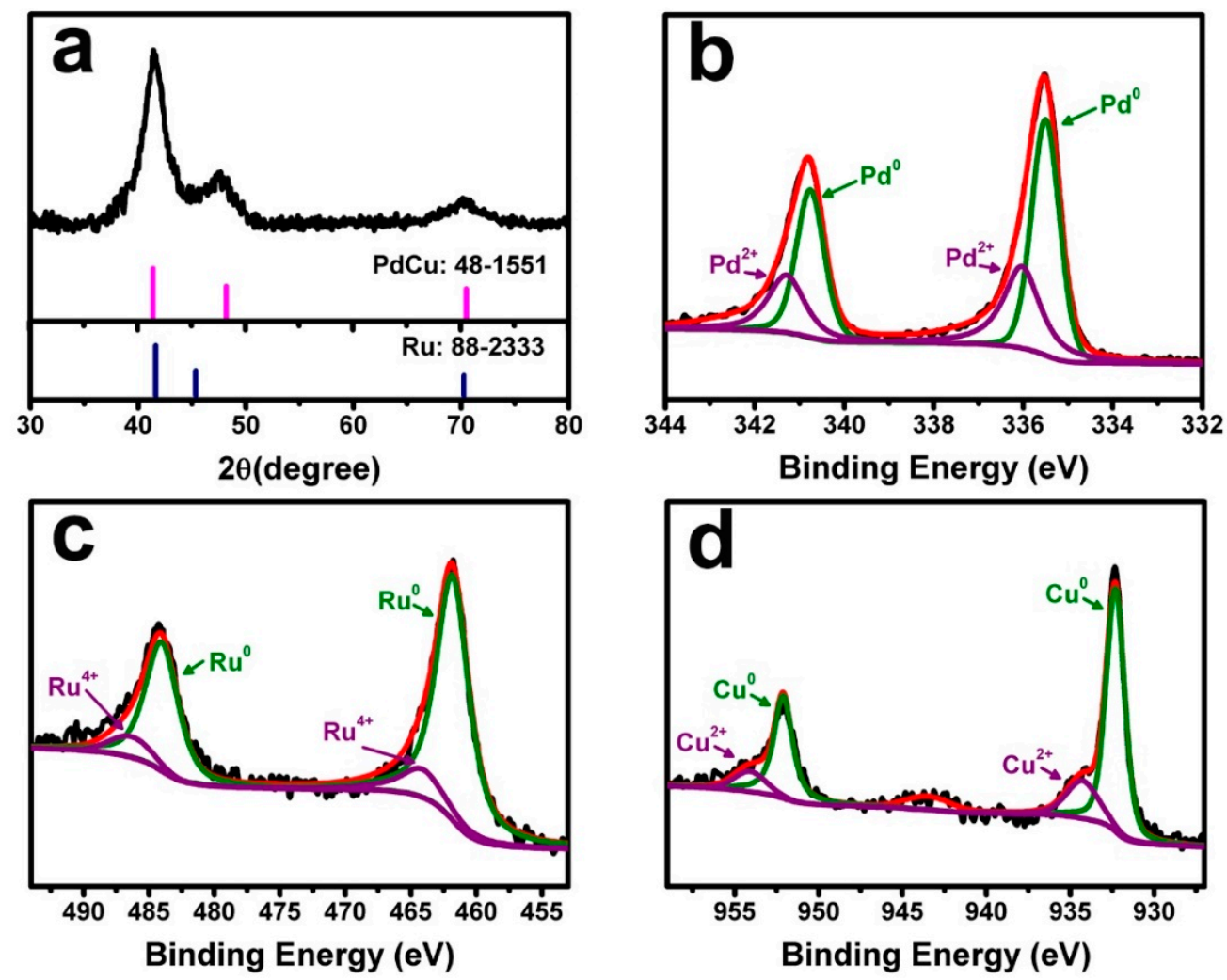

Figure 5. (a) XRD pattern, (b) high-resolution Pd 3d, (c) Ru 3p, and (d) Cu 2p XPS spectra of the $\mathrm{Pd}_{24} \mathrm{Cu}_{29} \mathrm{Ru}_{47}$ nanoplates.

The high-resolution XPS spectra were employed to determine the valence state of $\mathrm{Pd} 3 \mathrm{~d}, \mathrm{Ru} 3 \mathrm{p}$, and $\mathrm{Cu} 2 \mathrm{p}$ of the $\mathrm{Pd}_{24} \mathrm{Cu}_{29} \mathrm{Ru}_{47}$ nanoplates (Figure $5 \mathrm{~b}-\mathrm{d}$ ). As observed, all three elements mainly exist in the metallic state. As shown in Figure $5 b$, two representative XPS peaks with the binding energies of 335.5 and $340.8 \mathrm{eV}$ can be assigned to metallic $P d 3 d_{5 / 2}$ and $3 d_{3 / 2}$, respectively. Whereas other two weak peaks at 336.0 and $341.3 \mathrm{eV}$ can be attributed to the bivalent $\mathrm{Pd}^{2+}$. All these peaks are positively shifted in binding energy relative to those of the pure counterparts. Noticeably, an opposite trend associated with $\mathrm{Ru} 3 \mathrm{p}$ and $\mathrm{Cu} 2 \mathrm{p}$ was observed in the $\mathrm{Pd}_{24} \mathrm{Cu}_{29} \mathrm{Ru}_{47}$ nanoplate. These results demonstrated that a strong electron coupling occurred between $\mathrm{Pd}, \mathrm{Ru}$, and $\mathrm{Cu}$. Similarly, the occurrence of electron transfer has been confirmed for other two PdCuRu nanoplates (Figures S5 and S6). Such electron coupling might be expected to boost the catalytic activity of the HER electrocatalysts since Ru can weaken hydrogen adsorption and is highly efficient in water dissociation in alkaline electrolyte [38,39]. 
Recently, we have developed a general method for the synthesis of multimetallic Pd@PtM ( $\mathrm{M}=\mathrm{Ni}, \mathrm{Rh}, \mathrm{Ru})$ nanoplates using Pd nanoplates as the templates [31]. For comparison, the introduction of $\mathrm{Cu}$ here results in the formation of the porous nanoplates, indicating the critical role of $\mathrm{Cu}$. First, previous study indicated that only $\mathrm{Cu}^{2+}$ ions cannot be reduced by benzyl alcohol [40]. On the contrary, Ru nanoparticles are often obtained through the reduction of $\mathrm{Ru}^{3+}$ ions by polyol [40-42]. In this work, the presence of the Pd nanoplates facilitates the reduction of $\mathrm{Cu}^{2+}$ ions to $\mathrm{Cu}$ atoms prior to $\mathrm{Ru}$ precursor due to the well-known underpotential deposition (UPD) [43]. This demonstration is supported by the ICP-AES data (Figure $6 \mathrm{~d}$ and Table S2), showing the much higher atomic ratio of $\mathrm{Cu}$ than $\mathrm{Ru}$ atoms in the product in the initial stage. According to our previous result [44], the newly formed $\mathrm{Cu}$ atoms could interdiffuse with Pd atoms to form alloys at $200{ }^{\circ} \mathrm{C}$ (i.e., Kirkendall effect). In addition, the strain arising from the twinned structure of the $\mathrm{Pd}$ nanoplates accelerated the out-diffusion of Pd atoms [44], breaking the plate-like structures. Certainly, the ultrathin Pd nanoplates $(1.1 \mathrm{~nm})$ is vulnerable to the variation of the strain during the interdiffusion, and may tend to be broken. The control experiment in the absence of Ru precursor (Figure 6a) shows that the Pd plate-like seeds converted into small nanoparticles, induced by the addition of $\mathrm{Cu}$ precursor. While, the plate-like nanostructures were maintained accompanying with some small triangular particles in the absence of $\mathrm{Cu}$ precursor (Figure $6 \mathrm{~b}$, marked by white arrows). This result further confirms that the addition of $\mathrm{Cu}$ is a key to induce the porous structures. Second, the newly formed $\mathrm{Cu}$ atoms and even the ones in alloys can reduce the $\mathrm{Ru}$ precursors through galvanic replacement due to the more negative reduction potential of $\mathrm{Cu}\left(\mathrm{Cu}^{2+} / \mathrm{Cu}: \sim 0.34 \mathrm{~V}\right)$ than $\mathrm{Ru}\left(\mathrm{Ru}^{3+} / \mathrm{Ru}\right.$ : $\sim 0.68 \mathrm{~V}$ ) $[45,46]$. Such galvanic replacement also lead to the porous structures and the formation of CuRu alloys. Figure 6c shows TEM images of the product in the presence of $\mathrm{Cu}$ and Ru precursors without the Pd nanoplates. As can be seen, the hollow nanostructures were generated through galvanic replacement between $\mathrm{Cu}$ and Ru precursor (marked by white arrows). Of course, Ru precursors can be reduced by benzyl alcohol (Figure 6b). Our previous study indicated that the $f c c$-structured $\mathrm{Ru}$ was generated due to the induction of the $\mathrm{Pd}$ and/or $\mathrm{Cu} f c c$ lattice [37]. The deposition of Ru on the surface of the porous nanoplates can decrease the size of the pores. Based on these results, the formation process of the porous plates can be summarized as follows: $\mathrm{Cu}^{2+}$ ions are preferentially reduced through UPD and deposited on the Pd plates. The atomic ratio of $\mathrm{Cu}$ in PdCuRu reaches $40.1 \%$ closing to that of $\mathrm{Pd}$ when reacting for $5 \mathrm{~min}$ (Table S2). The newly formed $\mathrm{Cu}$ atoms not only alloy with Pd through interdiffusion, but also reduce $\mathrm{Ru}^{3+}$ ions through galvanic replacement, resulting in the formation of the porous structures. The time-dependent TEM images in Figure S7 show that the porous structures are formed in the initial stage (5 min). With the extension of reaction time, the porous structures are remained, but their sizes decrease slightly. Simultaneously, the atomic ratio of $\mathrm{Cu}$ decreases, while the atomic ratios of Ru increases (Table S1). As such, the deposition of Ru on the porous nanoplates might be responsible for the decrease in the size of the pores.

The PdCuRu nanoplates were loaded on carbon support (Vulcan XC-72R), and then evaluated as the electrocatalysts for HER with commercial $\mathrm{Pt} / \mathrm{C}, \mathrm{Pd} / \mathrm{C}$, and $\mathrm{Ru} / \mathrm{C}$ as references. To clean the surface of these carbon-supported electrocatalysts, the cyclic voltammetry $(\mathrm{CV})$ was first conducted at room temperature in Ar-purged $0.1 \mathrm{M} \mathrm{KOH}$ solutions at a scan rate of $50 \mathrm{mV} \mathrm{s}^{-1}$ between 0 and $1.0 \mathrm{~V}$ versus reversible hydrogen electrode (RHE) for 50 cycles. All the HER measurements were carried out using a rotating disk electrode in $0.1 \mathrm{M} \mathrm{KOH}$ solution at a scan rate of $2 \mathrm{mV} \mathrm{s}^{-1}$ and a rotation rate of $1600 \mathrm{rpm}$ at room temperature. From polarization curves of these six samples (Figure $7 \mathrm{a}, \mathrm{c}$ ), their overpotentials at $10 \mathrm{~mA} \mathrm{~cm}{ }^{-2}$ decrease in the following order: $\mathrm{Pd} / \mathrm{C}>\mathrm{Ru} / \mathrm{C}>\mathrm{Pd}_{32} \mathrm{Cu}_{33} \mathrm{Ru}_{35} / \mathrm{C}>\mathrm{Pd}_{19} \mathrm{Cu}_{25} \mathrm{Ru}_{56} / \mathrm{C}>\mathrm{Pt} / \mathrm{C}>\mathrm{Pd}_{24} \mathrm{Cu}_{29} \mathrm{Ru}_{47} / \mathrm{C}$. As such, the $\mathrm{Pd}_{24} \mathrm{Cu}_{29} \mathrm{Ru}_{47} / \mathrm{C}$ exhibited the best activity for HER with an overpotential of $40.7 \mathrm{mV}$, outperforming those of $\mathrm{Pt} / \mathrm{C}(65 \mathrm{mV}), \mathrm{Pd}_{19} \mathrm{Cu}_{25} \mathrm{Ru}_{56} / \mathrm{C}(76 \mathrm{mV}), \mathrm{Pd}_{32} \mathrm{Cu}_{33} \mathrm{Ru}_{35} / \mathrm{C}$ $(80 \mathrm{mV}), \mathrm{Ru} / \mathrm{C}(92 \mathrm{mV})$, and $\mathrm{Pd} / \mathrm{C}(397 \mathrm{mV}$, Figure $7 \mathrm{~d})$. Figure $7 \mathrm{~b}$ shows the linear Tafel plots of three $\mathrm{PdCuRu}$ porous nanoplates including commercial $\mathrm{Pt} / \mathrm{C}$ by fitting the Tafel 
equation. As observed, the $\mathrm{Pd}_{24} \mathrm{Cu}_{29} \mathrm{Ru}_{47} / \mathrm{C}$ achieved the lowest Tafel slope with a value of $37.5 \mathrm{mV} \mathrm{dec}^{-1}$, indicating the faster reaction kinetics of the $\mathrm{Pd}_{24} \mathrm{Cu}_{29} \mathrm{Ru}_{47} / \mathrm{C}$ than the $\mathrm{Pt} / \mathrm{C}$ $\left(42.0 \mathrm{mVdec}^{-1}\right), \mathrm{Pd}_{19} \mathrm{Cu}_{25} \mathrm{Ru}_{56} / \mathrm{C}\left(57.5 \mathrm{mV} \mathrm{dec}^{-1}\right)$, and $\mathrm{Pd}_{32} \mathrm{Cu}_{33} \mathrm{Ru}_{35} / \mathrm{C}\left(80.9 \mathrm{mV} \mathrm{dec}{ }^{-1}\right)$. In addition, the electrochemically active surface area (ECSA) of the PdCuRu/C was determined by measuring the double-layer capacitance [47]. The capacitances of the double-layer at the solid-liquid interface were calculated from the CV curves obtained over a potential range of $0.74-0.94 \mathrm{~V}$ (vs. RHE) at different scan rates from 20 to $200 \mathrm{mV} \mathrm{s}^{-1}$ in $0.1 \mathrm{M}$ $\mathrm{KOH}$ (Figure S8). The specific capacitances for the $\mathrm{Pd}_{32} \mathrm{Cu}_{33} \mathrm{Ru}_{35} / \mathrm{C}, \mathrm{Pd}_{24} \mathrm{Cu}_{29} \mathrm{Ru}_{47} / \mathrm{C}$ and $\mathrm{Pd}_{19} \mathrm{Cu}_{25} \mathrm{Ru}_{56} / \mathrm{C}$ were $5.25,8,61$, and $4.71 \mathrm{mF} \mathrm{cm}{ }^{-2}$, respectively (Figure $7 \mathrm{e}$ ). As such, the corresponding ECSA of the $\mathrm{Pd}_{24} \mathrm{Cu}_{29} \mathrm{Ru}_{47} / \mathrm{C}\left(42.20 \mathrm{~cm}^{2}\right)$ was larger than that of the $\mathrm{Pd}_{32} \mathrm{Cu}_{33} \mathrm{Ru}_{35} / \mathrm{C}\left(25.73 \mathrm{~cm}^{2}\right)$ and $\mathrm{Pd}_{19} \mathrm{Cu}_{25} \mathrm{Ru}_{56} / \mathrm{C}\left(23.08 \mathrm{~cm}^{2}\right)$, indicating more active sites existing in the $\mathrm{Pd}_{24} \mathrm{Cu}_{29} \mathrm{Ru}_{47} / \mathrm{C}$ due to the porous structures [48,49]. Figure S9 shows the HER polarization curves of such three $\mathrm{PdCuRu} / \mathrm{C}$ catalysts normalized by ECSA, further confirming the better intrinsic activity of the $\mathrm{Pd}_{24} \mathrm{Cu}_{29} \mathrm{Ru}_{47} / \mathrm{C}$ relative to $\mathrm{Pd}_{32} \mathrm{Cu}_{33} \mathrm{Ru}_{35} / \mathrm{C}$ and $\mathrm{Pd}_{19} \mathrm{Cu}_{25} \mathrm{Ru}_{56} / \mathrm{C}$.
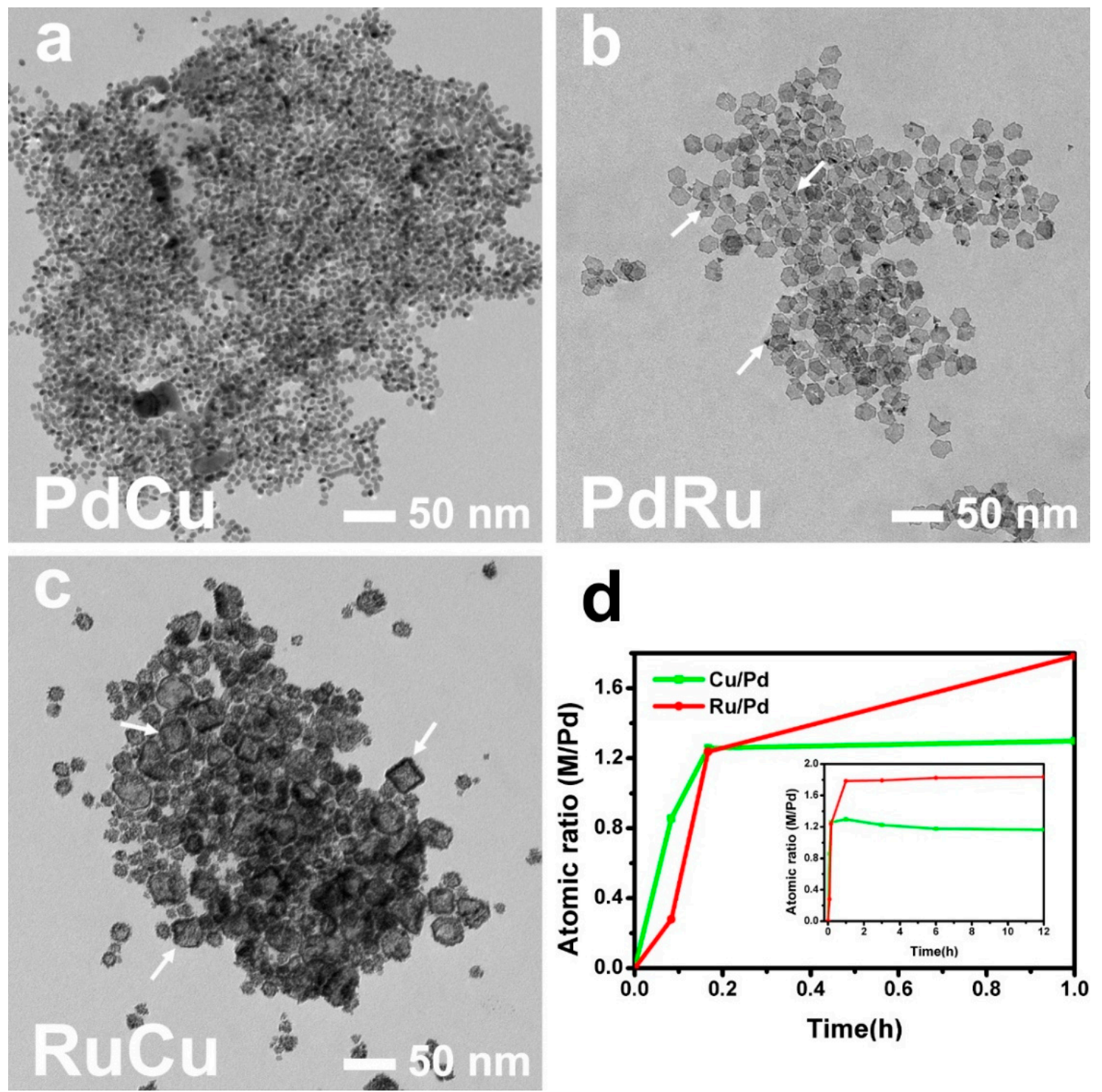

Figure 6. TEM images of the products prepared using the standard procedure, except for (a) in the absence of Ru precursor, (b) in the absence of $\mathrm{Cu}$ precursor, (c) in the absence of Pd seeds. (d) The variation in the atomic ratio of $\mathrm{Cu}$ and $\mathrm{Ru}$ to $\mathrm{Pd}$ for the $\mathrm{Pd}_{24} \mathrm{Cu}_{29} \mathrm{Ru}_{47}$ nanoplates at different reaction time measured by ICP-AES technique. 

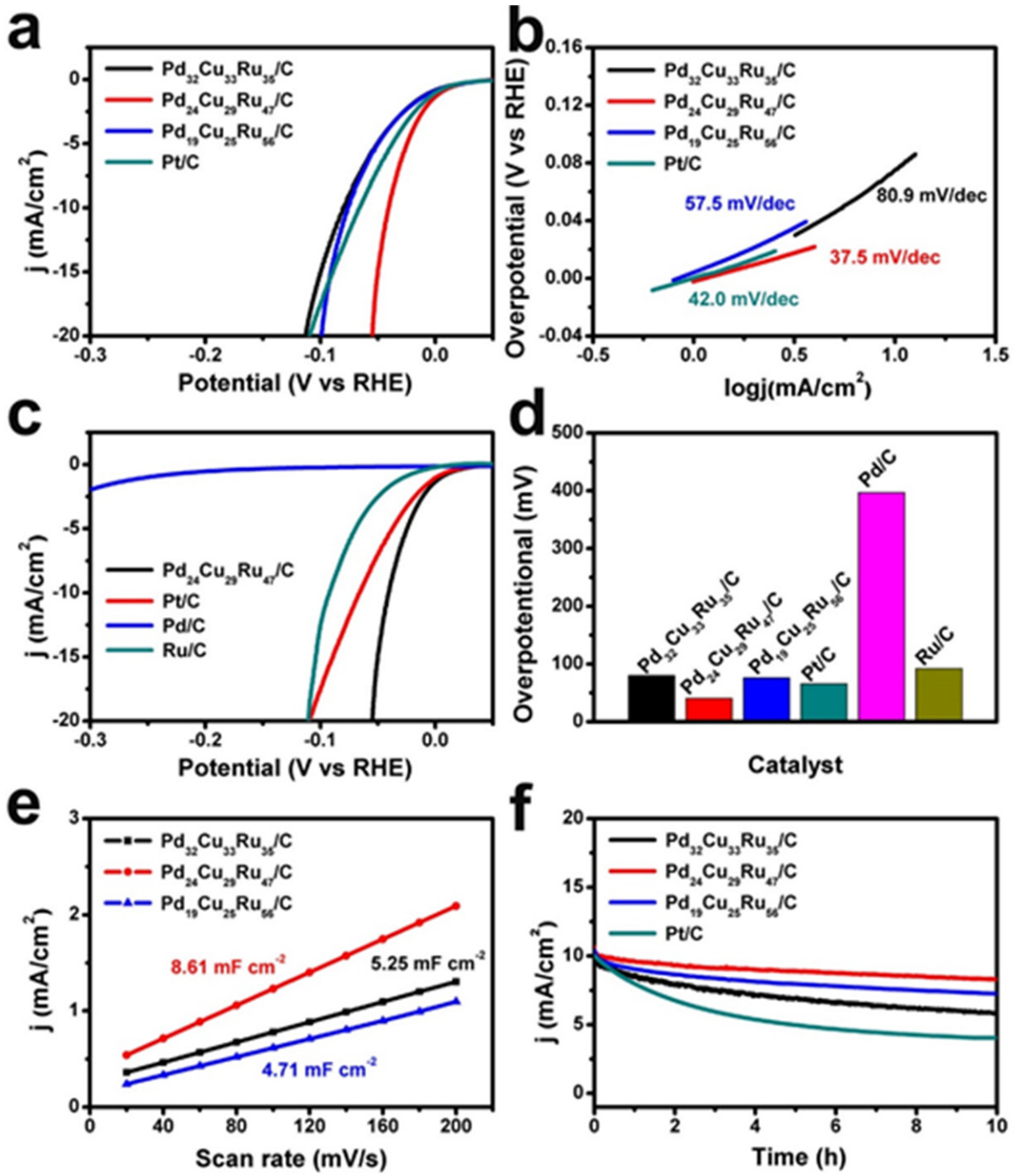

Figure 7. (a) HER polarization curves and (b) corresponding Tafel plots. (c) HER polarization curves of the $\mathrm{Pd}_{24} \mathrm{Cu}_{29} \mathrm{Ru}_{47} / \mathrm{C}$, commercial $\mathrm{Ru} / \mathrm{C}, \mathrm{Pd} / \mathrm{C}$ and $\mathrm{Pt} / \mathrm{C}$ normalized by geometric surface area of RDE in $0.1 \mathrm{M} \mathrm{KOH}$ solutions. (d) Comparison of the overpotential values required to achieve a cathodic current density of $10 \mathrm{~mA} \mathrm{~cm}^{-2}$ for all the catalysts. (e) Electrochemical double-layer capacitance $\left(\mathrm{Cd}_{1}\right)$ of the $\mathrm{Pd}_{32} \mathrm{Cu}_{33} \mathrm{Ru}_{35} / \mathrm{C}, \mathrm{Pd}_{24} \mathrm{Cu}_{29} \mathrm{Ru}_{47} / \mathrm{C}$ and $\mathrm{Pd}_{19} \mathrm{Cu}_{25} \mathrm{Ru}_{56} / \mathrm{C}$. (f) Chronoamperometry measurements of the commercial $\mathrm{Pt} / \mathrm{C}, \mathrm{Pd}_{32} \mathrm{Cu}_{33} \mathrm{Ru}_{35} / \mathrm{C}, \mathrm{Pd}_{24} \mathrm{Cu}_{29} \mathrm{Ru}_{47} / \mathrm{C}$, and $\mathrm{Pd}_{19} \mathrm{Cu}_{25} \mathrm{Ru}_{56} / \mathrm{C}$ at an overpotential with the current density being $10 \mathrm{~mA} / \mathrm{cm}^{2}$ in $0.1 \mathrm{M} \mathrm{KOH}$ for $10 \mathrm{~h}$.

As is well-known, $\mathrm{Pt}$ is difficult to dissociate water, leading to unsatisfactory activity for HER in alkaline solution. As an oxophilic metal, Ru is active to catalyze the dissociation of water and holds great potential as highly efficient electrocatalysts for HER in an alkaline solution. The strong electron coupling between $\mathrm{Pd}, \mathrm{Cu}$ and $\mathrm{Ru}$ could optimize the binding energy of $\mathrm{Ru}-\mathrm{H}$, which results in a weak hydrogen adsorption on the surface of the PdCuRu nanoplates [50]. On the other hand, $\mathrm{Cu}$ could accelerate the electron transfer between $\mathrm{Ru}$ and the adsorbate. At the same time, $\mathrm{Cu}$ near the pores will assist in the stabilization of $\mathrm{Ru}$ [38]. These two features endow the $\mathrm{Pd}_{24} \mathrm{Cu}_{29} \mathrm{Ru}_{47} / \mathrm{C}$ with higher HER activity than commercial $\mathrm{Pt} / \mathrm{C}$. Besides, due to the optimized area percentage of pore structures and proportion of $\mathrm{Ru}, \mathrm{Pd}_{24} \mathrm{Cu}_{29} \mathrm{Ru}_{47} / \mathrm{C}$ achieved the highest HER activity among three kinds of the $\mathrm{PdCuRu} / \mathrm{C}$. Furthermore, the $\mathrm{Pd}_{24} \mathrm{Cu}_{29} \mathrm{Ru}_{47} / \mathrm{C}$ exhibited the smallest charge transfer resistance (21.02 $\Omega$ ) in the PdCuRu/C during the HER process (Figure S10), similar to that of commercial Pt/C (22.54 $\Omega$ ). It is indicated that the HER kinetics at the interface of such catalysts is more efficient than other catalysts (Figure S10). Significantly, the stability of the PdCuRu/C and Pt/C was evaluated in 0.1 M KOH solution by current-time (I-t) 
curves with a constant current density of $10 \mathrm{~mA} \mathrm{~cm}^{-2}$, as shown in Figure 7f. Clearly, the three $\mathrm{PdCuRu} / \mathrm{C}$ show the higher steady current density relative to commercial $\mathrm{Pt} / \mathrm{C}$ for HER over the entire time range, indicating their superior durability. Among them, the $\mathrm{Pd}_{24} \mathrm{Cu}_{29} \mathrm{Ru}_{47} / \mathrm{C}$ remained the highest activity $\left(8.30 \mathrm{~mA} \mathrm{~cm}{ }^{-2}, 17 \%\right.$ drop $)$ after $10 \mathrm{~h}$, which is much larger than that of the $\mathrm{Pd}_{32} \mathrm{Cu}_{33} \mathrm{Ru}_{35} / \mathrm{C}\left(5.86 \mathrm{~mA} \mathrm{~cm}{ }^{2}\right), \mathrm{Pd}_{19} \mathrm{Cu}_{25} \mathrm{Ru}_{56} / \mathrm{C}$ $\left(7.25 \mathrm{~mA} \mathrm{~cm}^{2}\right)$ and commercial $\mathrm{Pt} / \mathrm{C}\left(4.05 \mathrm{~mA} \mathrm{~cm}^{-2}, 59.5 \%\right.$ drop). Figure $\mathrm{S} 11$ shows TEM images of the $\mathrm{Pd}_{32} \mathrm{Cu}_{33} \mathrm{Ru}_{35} / \mathrm{C}, \mathrm{Pd}_{24} \mathrm{Cu}_{29} \mathrm{Ru}_{47} / \mathrm{C}$, and $\mathrm{Pd}_{19} \mathrm{Cu}_{25} \mathrm{Ru}_{56} / \mathrm{C}$ before and after I-t measurements. Obviously, the nanoplates are still well-dispersed on the carbon support, which is responsible for the superior stability. We have performed EDX technique to analyze the variation of element distribution of the $\mathrm{Pd}_{24} \mathrm{Cu}_{29} \mathrm{Ru}_{47} / \mathrm{C}$ after durability test (Figure S12). From the EDX mapping image and line-scan profile, Ru is still richened on the surface, while, $\mathrm{Pd}$ and $\mathrm{Cu}$ mainly exist in the interior of the nanoplates. Clearly, some of them leached from the nanoplates, leading to the much more pores. The poor stability of commercial $\mathrm{Pt} / \mathrm{C}$ can be attributed to the weak capability of water dissociation and easy aggregation of small $\mathrm{Pt}$ nanoparticles on carbon support.

\section{Conclusions}

In summary, we have successfully developed a facile one-pot solvothermal method to synthesize the PdCuRu porous nanoplates with different compositions of Ru. Secondly, the formation mechanism of the porous nanoplates were clearly revealed, and involves the deposition of $\mathrm{Cu}$ on $\mathrm{Pd}$, alloying $\mathrm{Cu}$ with $\mathrm{Pd}$ by interdiffusion, and reduction of Ru precursor by galvanic replacement with $\mathrm{Cu}$. These three $\mathrm{PdCuRu}$ porous nanoplates exhibited the excellent catalytic activity toward HER in alkaline solution, with the $\mathrm{Pd}_{24} \mathrm{Cu}_{29} \mathrm{Ru}_{47} / \mathrm{C}$ being the best HER electrocatalysts. Specifically, the $\mathrm{Pd}_{24} \mathrm{Cu}_{29} \mathrm{Ru}_{47} / \mathrm{C}$ achieved the lowest overpotential $(40.7 \mathrm{mV})$ and smallest Tafel slope $\left(37.5 \mathrm{mV} \mathrm{dec}^{-1}\right)$, which are superior to those of commercial $\mathrm{Pt} / \mathrm{C}$. In addition, these nanoplates also showed substantially enhanced stability relative to $\mathrm{Pt} / \mathrm{C}\left(17 \%\right.$ drop for the $\mathrm{Pd}_{24} \mathrm{Cu}_{29} \mathrm{Ru}_{47} / \mathrm{C}$ versus $59.5 \%$ drop for $\mathrm{Pt} / \mathrm{C})$. Fourth, such enhancement in activity and durability can be attributed to the electron coupling between three metals, unique porous structure, and strong capability of Ru for water dissociation. This work provides a simple strategy to design advanced Ru-based electrocatalysts for HER.

Supplementary Materials: The following are available online at https:/ / www.mdpi.com/article/10 $.3390 /$ met11091451/s1. Figure S1. (a) TEM image of the Pd plate-like seeds that lay flat on the TEM grid and (b) the corresponding edge length. Figure S2. (a) TEM image of vertically upstanding of $\mathrm{Pd}_{24} \mathrm{Cu}_{29} \mathrm{Ru}_{47}$ nanoplates and (b) the corresponding thickness. The nanoplates were firstly mixed with carbon nanotubes in an aqueous solution. After centrifugation, the product was collected and measured by TEM analysis. The width of the projection for the vertically upstanding nanoplates is the corresponding thickness. Figure S3. The size and average area percentage of the pores in three nanoplates with different amount of $\mathrm{Ru}$ : (a) $\mathrm{Pd}_{32} \mathrm{Cu}_{33} \mathrm{Ru}_{35}$ nanoplates, (b) $\mathrm{Pd}_{24} \mathrm{Cu}_{29} \mathrm{Ru}_{47}$ nanoplates, and (c) $\mathrm{Pd}_{19} \mathrm{Cu}_{25} \mathrm{Ru}_{56}$ nanoplates. Figure S4. XRD patterns of the $\mathrm{Pd}_{32} \mathrm{Cu}_{33} \mathrm{Ru}_{35}, \mathrm{Pd}_{24} \mathrm{Cu}_{29} \mathrm{Ru}_{47}$ and $\mathrm{Pd}_{19} \mathrm{Cu}_{25} \mathrm{Ru}_{56}$ nanoplates. Figure S5. High-resolution (a) Pd 3d, (b) Ru 3p, and (c) Cu 2p XPS spectra of the $\mathrm{Pd}_{32} \mathrm{Cu}_{33} \mathrm{Ru}_{35}$ nanoplates. Figure S6. High-resolution (a) Pd 3d, (b) $\mathrm{Ru} 3 p$, and (c) Cu 2p XPS spectra of the $\mathrm{Pd}_{19} \mathrm{Cu}_{25} \mathrm{Ru}_{56}$ nanoplates. Figure S7. TEM images of the product prepared using the standard procedure except for different reaction times: (a) $5 \mathrm{~min}$, (b) $10 \mathrm{~min}$, (c) $1 \mathrm{~h}$, (d) $3 \mathrm{~h}$, (e) $6 \mathrm{~h}$, and (f) $12 \mathrm{~h}$. Figure S8. Cyclic voltammograms (CV) with scan rates from 20 to $200 \mathrm{mV} \mathrm{s}^{-1}$ of (a) $\mathrm{Pd}_{32} \mathrm{Cu}_{33} \mathrm{Ru}_{35} / \mathrm{C}$, (b) $\mathrm{Pd}_{24} \mathrm{Cu}_{29} \mathrm{Ru}_{47} / \mathrm{C}$ and (c) $\mathrm{Pd}_{19} \mathrm{Cu}_{25} \mathrm{Ru}_{56} / \mathrm{C}$ that were performed in a potential window without faradaic processes. Figure S9. HER polarization curves normalized by the ECSA for the $\mathrm{Pd}_{32} \mathrm{Cu}_{33} \mathrm{Ru}_{35} / \mathrm{C}, \mathrm{Pd}_{24} \mathrm{Cu}_{29} \mathrm{Ru}_{47} / \mathrm{C}$ and $\mathrm{Pd}_{19} \mathrm{Cu}_{25} \mathrm{Ru}_{56} / \mathrm{C}$ in $0.1 \mathrm{M} \mathrm{KOH}$ solution. Figure S10. Electrochemical impedance spectroscopy (EIS) curves of various electrocatalysts. Figure S11. TEM images of $(\mathrm{a}, \mathrm{d}) \mathrm{Pd}_{32} \mathrm{Cu}_{33} \mathrm{Ru}_{35} / \mathrm{C}$, (b,e) $\mathrm{Pd}_{24} \mathrm{Cu}_{29} \mathrm{Ru}_{47} / \mathrm{C}$ and (c,f) $\mathrm{Pd}_{19} \mathrm{Cu}_{25} \mathrm{Ru}_{56} / \mathrm{C}$ catalysts before and after the chronoamperometric measurement, correspondingly. Figure S12. (a) HAADF-STEM, (b) EDX mapping images of a planar $\mathrm{Pd}_{24} \mathrm{Cu}_{29} \mathrm{Ru}_{47}$ nanoplate after I-t testing. (c) HAADF-STEM and EDX images of a vertically upstanding $\mathrm{Pd}_{24} \mathrm{Cu}_{29} \mathrm{Ru}_{47}$ nanoplate after I-t testing. Pd (orange), $\mathrm{Ru}$ (red), $\mathrm{Cu}$ (green). (d) Line-scan profiles along the side of a $\mathrm{Pd}_{24} \mathrm{Cu}_{29} \mathrm{Ru}_{47}$ nanoplate after I-t testing. 
Table S1. ICP-AES data of the PdCuRu multimetallic nanoplates with different atomic ratios and the molar ratio of the $\mathrm{Pd}, \mathrm{Cu}$ and $\mathrm{Ru}$ precursors fed in the synthesis. Table S2. The variation in the atomic percentage of $\mathrm{Pd}, \mathrm{Cu}$, and $\mathrm{Ru}$ for the $\mathrm{Pd}_{24} \mathrm{Cu}_{29} \mathrm{Ru}_{47}$ nanoplates with the reaction time measured by ICP-AES technique.

Author Contributions: C.C. performed the experiments, analyzed the data, and wrote the paper draft. N.Q. assisted in performing the experiments. X.L. carried out the TEM analysis. J.L. performed electrochemical measurement. D.Y. analyzed the data and revised the paper. H.Z. directed the research, analyzed the data, and revised the paper. All authors have read and agreed to the published version of the manuscript.

Funding: This work is supported by the National Science Foundation of China $(51522103,51871200$, and 61721005) and National Program for Support of Top-notch Young Professionals.

Institutional Review Board Statement: Not applicable.

Informed Consent Statement: Not applicable.

Data Availability Statement: The data presented in this study are available on request from the corresponding author.

Acknowledgments: The work on electron microscopy was carried out in the Center for Electron Microscopy of Zhejiang University.

Conflicts of Interest: The authors declare no conflict of interest.

\section{References}

1. Dresselhaus, M.S.; Thomas, I.L. Alternative energy technologies. Nature 2001, 414, 332-337. [CrossRef]

2. Seh, Z.W.; Kibsgaard, J.; Dickens, C.F.; Chorkendorff, I.; Norskov, J.K.; Jaramillo, T.F. Combining theory and experiment in electrocatalysis: Insights into materials design. Science 2017, 355, 4998. [CrossRef] [PubMed]

3. Jiang, Y.; Wu, X.; Yan, Y.; Luo, S.; Li, X.; Huang, J.; Zhang, H.; Yang, D. Coupling PtNi ultrathin nanowires with MXenes for boosting electrocatalytic hydrogen evolution in both acidic and alkaline Solutions. Small 2019, 15, 1805474. [CrossRef] [PubMed]

4. Ataee-Esfahani, H.; Imura, M.; Yamauchi, Y. All-metal mesoporous nanocolloids: Solution-phase synthesis of core-shell Pd@Pt nanoparticles with a designed concave surface. Angew. Chem. 2013, 52, 13611-13615. [CrossRef]

5. Turner, J.A. Sustainable hydrogen production. Science 2004, 305, 972-974. [CrossRef]

6. $\quad$ Bhavsar, S.; Najera, M.; Solunke, R.; Veser, G. Chemical looping: To combustion and beyond. Catal. Today 2014, 228, 96-105. [CrossRef]

7. You, B.; Sun, Y. Innovative strategies for electrocatalytic water splitting. Acc. Chem. Res 2018, 51, 1571-1580. [CrossRef]

8. Zheng, Y.; Jiao, Y.; Jaroniec, M.; Qiao, S.Z. Advancing the electrochemistry of the hydrogen-evolution reaction through combining experiment and theory. Angew. Chem. 2015, 54, 52-65. [CrossRef] [PubMed]

9. Xu, J.Y.; Liu, T.F.; Li, J.J.; Li, B.; Liu, Y.F.; Zhang, B.S.; Xiong, D.H.; Amorim, I.; Li, W.; Liu, L.F. Boosting the hydrogen evolution performance of ruthenium clusters through synergistic coupling with cobalt phosphide. Energy Environ. Sci. 2018, 11, 1819-1827. [CrossRef]

10. Durst, J.; Siebel, A.; Simon, C.; Hasche, F.; Herranz, J.; Gasteiger, H.A. New insights into the electrochemical hydrogen oxidation and evolution reaction mechanism. Energy Environ. Sci. 2014, 7, 2255-2260. [CrossRef]

11. Geng, Z.; Liu, Y.; Kong, X.; Li, P.; Li, K.; Liu, Z.; Du, J.; Shu, M.; Si, R.; Zeng, J. Achieving a record-high yield rate of $120.9 \mu \mathrm{g}_{\mathrm{NH} 3} \mathrm{mg}^{-1}$ cat $^{-1}$ for $\mathrm{N}_{2}$ electrochemical reduction over Ru single-atom catalysts. Adv. Mater. 2018, 30, 1803498. [CrossRef]

12. Zheng, Y.; Jiao, Y.; Zhu, Y.; Li, L.; Han, Y.; Chen, Y.; Jaroniec, M.; Qiao, S.Z. High electrocatalytic hydrogen evolution activity of an anomalous ruthenium catalyst. J. Am. Chem. Soc. 2016, 138, 16174-16181. [CrossRef]

13. Li, W.D.; Liu, Y.; Wu, M.; Feng, X.L.; Redfern, S.A.T.; Shang, Y.; Yong, X.; Feng, T.L.; Wu, K.F.; Liu, Z.Y.; et al. Carbon-quantumdots-loaded ruthenium nanoparticles as an efficient electrocatalyst for hydrogen production in alkaline media. Adv. Mater. 2018, 30, 1800676. [CrossRef]

14. Ge, J.; He, D.; Bai, L.; You, R.; Lu, H.; Lin, Y.; Tan, C.; Kang, Y.B.; Xiao, B.; Wu, Y.; et al. Ordered porous Pd octahedra covered with mono layer Ru atoms. J. Am. Chem. Soc. 2015, 137, 14566-14569. [CrossRef]

15. Zhang, Z.; Xu, B.; Wang, X. Engineering nanointerfaces for nanocatalysis. Chem. Soc. Rev. 2014, 43, 7870-7886. [CrossRef] [PubMed]

16. Shao, M.; Shoemaker, K.; Peles, A.; Kaneko, K.; Protsailo, L. Pt mono layer on porous Pd-Cu alloys as oxygen reduction electrocatalysts. J. Am. Chem. Soc. 2010, 132, 9253-9255. [CrossRef]

17. Xiong, Y.; Shan, H.; Zhou, Z.; Yan, Y.; Chen, W.; Yang, Y.; Liu, Y.; Tian, H.; Wu, J.; Zhang, H.; et al. Tuning surface structure and strain in Pd-Pt core-shell nanocrystals for enhanced electrocatalytic oxygen reduction. Small 2017, 13, 1603423. [CrossRef] [PubMed] 
18. Su, J.; Yang, Y.; Xia, G.; Chen, J.; Jiang, P.; Chen, Q. Ruthenium-cobalt nanoalloys encapsulated in nitrogen-doped graphene as active electrocatalysts for producing hydrogen in alkaline media. Nat. Commun. 2017, 8, 14969. [CrossRef]

19. Zhang, D.; Zhao, H.; Huang, B.; Li, B.; Li, H.; Han, Y.; Wang, Z.; Wu, X.; Pan, Y.; Sun, Y.; et al. Advanced ultrathin RuPdM (M = $\mathrm{Ni}, \mathrm{Co}, \mathrm{Fe}$ ) nanosheets electrocatalyst boosts hydrogen evolution. ACS Central Science 2019, 5, 1991-1997. [CrossRef] [PubMed]

20. Fan, Z.; Huang, X.; Tan, C.; Zhang, H. Thin metal nanostructures: Synthesis, properties and applications. Chem. Sci. 2015, 6, 95-111. [CrossRef] [PubMed]

21. Zhang, Z.; Liu, Y.; Chen, B.; Gong, Y.; Gu, L.; Fan, Z.; Yang, N.; Lai, Z.; Chen, Y.; Wang, J.; et al. Submonolayered Ru deposited on ultrathin Pd nanosheets used for enhanced catalytic applications. Adv. Mater. 2016, 28, 10282-10286. [CrossRef]

22. Yin, X.; Liu, X.; Pan, Y.T.; Walsh, K.A.; Yang, H. Hanoi tower-like multi layered ultrathin palladium nanosheets. Nano Lett. 2014, 14, 7188-7194. [CrossRef]

23. Hong, J.W.; Kim, Y.; Wi, D.H.; Lee, S.; Lee, S.U.; Lee, Y.W.; Choi, S.I.; Han, S.W. Ultrathin free-standing ternary-alloy nanosheets. Angew. Chem. 2016, 55, 2753-2758. [CrossRef] [PubMed]

24. Duan, H.; Yan, N.; Yu, R.; Chang, C.R.; Zhou, G.; Hu, H.S.; Rong, H.; Niu, Z.; Mao, J.; Asakura, H.; et al. Ultrathin rhodium nanosheets. Nat. Commun. 2014, 5, 3093. [CrossRef]

25. Yan, Y.; Li, X.; Tang, M.; Zhong, H.; Huang, J.; Bian, T.; Jiang, Y.; Han, Y.; Zhang, H.; Yang, D. Tailoring the edge sites of 2D Pd nanostructures with different fractal dimensions for enhanced electrocatalytic performance. Adv. Sci. 2018, 5, 1800430. [CrossRef] [PubMed]

26. Wang, F.; Wang, Z.; Shifa, T.A.; Wen, Y.; Wang, F.; Zhan, X.; Wang, Q.; Xu, K.; Huang, Y.; Yin, L.; et al. Two-dimensional non-layered materials: Synthesis, properties and applications. Adv. Funct. Mater. 2017, 27, 1603254. [CrossRef]

27. Liz-Marzán, L.M.; Grzelczak, M. Growing anisotropic crystals at the nanoscale. Science 2017, 356, 1120-1121. [CrossRef] [PubMed]

28. Chen, Y.; Fan, Z.; Zhang, Z.; Niu, W.; Li, C.; Yang, N.; Chen, B.; Zhang, H. Two-dimensional metal nanomaterials: Synthesis, properties, and applications. Chem. Rev. 2018, 118, 6409-6455. [CrossRef]

29. Ding, J.; Shao, Q.; Feng, Y.; Huang, X. Ruthenium-nickel sandwiched nanoplates for efficient water splitting electrocatalysis. Nano Energy 2018, 47, 1-7. [CrossRef]

30. Yao, Q.; Huang, B.; Zhang, N.; Sun, M.; Shao, Q.; Huang, X. Channel-rich RuCu nanosheets for pH-universal overall water splitting electrocatalysis. Angew. Chem. Int. Ed. 2019, 58, 13983-13988. [CrossRef]

31. Yan, Y.; Shan, H.; Li, G.; Xiao, F.; Jiang, Y.; Yan, Y.; Jin, C.; Zhang, H.; Wu, J.; Yang, D. Epitaxial growth of multimetallic Pd@PtM $(\mathrm{M}=\mathrm{Ni}, \mathrm{Rh}, \mathrm{Ru})$ core-shell nanoplates realized by in situ-produced CO from interfacial catalytic reactions. Nano Lett. 2016, 16, 7999-8004. [CrossRef]

32. Kang, Y.; Snyder, J.; Chi, M.; Li, D.; More, K.; Markovic, N.; Stamenkovic, V. Multimetallic core/interlayer/shell nanostructures as advanced electrocatalysts. Nano Lett. 2014, 14, 6361-6367. [CrossRef]

33. Arán-Ais, R.; Dionigi, F.; Merzdorf, T.; Gocyla, M.; Heggen, M.; Dunin-Borkowski, R.; Gliech, M.; Solla-Gullón, J.; Herrero, E.; Feliu, J.; et al. Elemental anisotropic growth and atomic-scale structure of shape-controlled octahedral Pt-Ni-Co alloy nanocatalysts. Nano Lett. 2015, 15, 7473-7480. [CrossRef] [PubMed]

34. Lu, Q.; Wang, A.; Gong, Y.; Hao, W.; Cheng, H.; Chen, J.; Li, B.; Yang, N.; Niu, W.; Wang, J.; et al. Crystal phase-based epitaxial growth of hybrid noble metal nanostructures on $4 \mathrm{H} / \mathrm{fcc}$ Au nanowires. Nat. Chem. 2018, 10, 456-461. [CrossRef] [PubMed]

35. Li, Y.; Yan, Y.; Li, Y.; Zhang, H.; Li, D.; Yang, D. Size-controlled synthesis of Pd nanosheets for tunable plasmonic properties. CrystEngComm 2015, 17, 1833-1838. [CrossRef]

36. Li, Y.; Wang, W.; Xia, K.; Zhang, W.; Jiang, Y.; Zeng, Y.; Zhang, H.; Jin, C.; Zhang, Z.; Yang, D. Ultrathin two-dimensional Pd-based nanorings as catalysts for hydrogenation with high activity and stability. Small 2015, 11, 4745-4752. [CrossRef]

37. Han, Y.; Yan, Y.; Wu, Z.; Jiang, Y.; Li, X.; Xu, Q.; Yang, X.; Zhang, H.; Yang, D. Facile synthesis of Pd@Ru nanoplates with controlled thickness as efficient catalysts for hydrogen evolution reaction. CrystEngComm 2018, 20, 4230-4236. [CrossRef]

38. Wang, Y.; Wang, G.; Li, G.; Huang, B.; Pan, J.; Liu, Q.; Han, J.; Xiao, L.; Lu, J.; Zhuang, L. Pt-Ru catalyzed hydrogen oxidation in alkaline media: Oxophilic effect or electronic effect? Energy Environ. Sci. 2015, 8, 177-181. [CrossRef]

39. Lu, B.; Guo, L.; Wu, F.; Peng, Y.; Lu, J.E.; Smart, T.J.; Wang, N.; Finfrock, Y.Z.; Morris, D.; Zhang, P.; et al. Ruthenium atomically dispersed in carbon outperforms platinum toward hydrogen evolution in alkaline media. Nat. Commun. 2019, 10, 631. [CrossRef] [PubMed]

40. Song, Y.; Sun, J.; Zhang, Y.; Wang, B.; Li, Q.; Fan, Y. Facile synthesis of urchin-like RuCu and hollow RuCuMo nanoparticles and preliminary insight to their formation process by cyclic voltammetry. RSC Adv. 2018, 8, 14138-14143. [CrossRef]

41. Zhao, M.; Chen, Z.; Lyu, Z.; Hood, Z.; Xie, M.; Vara, M.; Chi, M.; Xia, Y. Ru octahedral nanocrystals with a face-centered cubic structure, $\{111\}$ facets, thermal stability up to $400{ }^{\circ} \mathrm{C}$, and enhanced catalytic activity. J. Am. Chem. Soc. 2019, 141, 7028-7036. [CrossRef] [PubMed]

42. Ren, Z.; Han, Y.; Cong, N.; Jin, L.; Tan, L.; Chen, H.; Zhai, C.; Zhou, X.; Fang, H.; Zhu, Y. Hydrothermal synthesis of spherical Ru with high efficiency hydrogen evolution activity. J. Electroanal. Chem. 2019, 848, 11320. [CrossRef]

43. Bian, T.; Liu, H.; Sun, B.; Xiao, B.; Jiang, Y.; Jin, C.; Yuan, A.; Zhang, H.; Yang, D. Ion-templated fabrication of Pt-Cu alloy octahedra with controlled compositions for electrochemical detection of $\mathrm{H}_{2} \mathrm{O}_{2}$. J. Alloy Compd. 2019, 788, 1334-1340. [CrossRef]

44. Huang, J.; Yan, Y.; Li, X.; Qiao, X.; Wu, X.; Li, J.; Shen, R.; Yang, D.; Zhang, H. Unexpected Kirkendall effect in twinned icosahedral nanocrystals driven by strain gradient. Nano Res. 2020, 13, 2641-2649. [CrossRef] 
45. Chen, A.; Endres, E.; Ashberry, H.; Bueno, S.; Chen, Y.; Skrabalak, S. Galvanic replacement of intermetallic nanocrystals as a route toward complex heterostructures. Nanoscale 2021, 13, 2618-2625. [CrossRef]

46. Wang, X.; Chen, S.; Reggiano, G.; Thota, S.; Wang, Y.; Kerns, P.; Suib, S.; Zhao, J. Au-Cu-M (M = Pt, Pd, Ag) nanorods with enhanced catalytic efficiency by galvanic replacement reaction. Chem. Commun. 2019, 55, 1249-1252. [CrossRef]

47. Ma, R.; Zhou, Y.; Chen, Y.; Li, P.; Liu, Q.; Wang, J. Ultrafine molybdenum carbide nanoparticles composited with carbon as a highly active hydrogen-evolution electrocatalyst. Angew. Chem. 2015, 54, 14723-14727. [CrossRef]

48. Wu, X.Q.; Jiang, Y.; Yan, Y.; Li, X.; Luo, S.; Huang, J.; Li, J.; Shen, R.; Yang, D.; Zhang, H. Tuning surface structure of $\mathrm{Pd}_{3} \mathrm{~Pb}-\mathrm{Pt} \mathrm{t}_{\mathrm{n}} \mathrm{Pb}$ nanocrystals for boosting the methanol oxidation reaction. Adv. Sci. 2019, 6, 1902249. [CrossRef]

49. Jagminas, A.; Naujokaitis, A.; Gaigalas, P.; Ramanavičius, S.; Kirtinaitiene, M.; Trusovas, R. Substrate impact on the structure and electrocatalyst properties of molybdenum disulfide for HER from water. Metals 2020, 10, 1251. [CrossRef]

50. Barman, B.; Sarkar, B.; Nanda, K. Pd-coated Ru nanocrystals supported on N-doped graphene as HER and ORR electrocatalysts. Chem. Commun. 2019, 55, 13928-13931. [CrossRef] 